\title{
Geological study of the Lesser Himalaya in the Kusma-Baglung area, western Nepal
}

\author{
*Nawraj Sapkota and Lalu P. Paudel \\ Central Department of Geology, Tribhuvan University, Kritipur, Kathmandu, Nepal
}

\begin{abstract}
Geological study was carried out along the Kaligandaki and Modi Khola valleys in west Nepal. The area comprises the rock of Lesser Himalayan metasedimentary sequence. Main rock types present in the area are quartzite, phyllite, metasandstone and psammatic phyllite. Schist and gneiss are present in some parts. Ulleri Gneiss is explored in the area. Kusma-Baglung area comprises the spectacular terrace deposits formed at the Quaternary time by the Kaligandaki River and the Modi Khola. The terrace extensively comprises clast of limestone, marble, gneiss, quartzite, schist, phyllite ranging in size from fine matrix to huge boulders derived from the Higher Himalaya.
\end{abstract}

Key words: Lesser Himalaya, Nepal, Nawakot Complex, river terrace, metamorphism

Received: 15 March 2018

Accepted: 20 June 2018

\section{INTRODUCTION}

The Kaligandaki valley in the Kusma-Baglung area lies in the inner part of the Lesser Himalaya in west Nepal. The study area comprises the rocks of metasedimentary sequences. Regional and few area-specific geological study has been carried out by many scientists such as Colchen et al. (1986); Dhital et al. (2002); Dhital (2015); Duvadi et al. (2004); Fuchs and Frank (1970); Godin (1999); Hagen (1969); Kaneko (1995); Le Fort (1975); Lamsal (2016); Paudel and Arita (1998, 2000); Upreti and Merh (1978) and Yamanaka et al. (1982). Similarly in the recent years few studies were carried out in the Kaligandaki River valley section. Paudel et al. (2017) studied the karst landforms and related geo-hazards in Kusma-Baglung area and identified the various karst structures like caves, karrens, sinkholes etc. The geological study comprises the area between Beni-Myagdi to Kusma-Parbat and surroundings. A geological map at a scale of 1:25,000 was prepared, structures and metamorphism of the area were also studied. This paper presents the results of geological mapping, structural analysis and petrographic study.

\section{LITHOSTRATIGRAPHY}

The study area lies in the Lower Nawakot Group of the Nawakot Complex in central Nepal. The Lesser Himalaya in central Nepal is made up of Late Pre-Cambrian rocks and classified into the Lower and Upper Nawakot Groups of Nawakot Complex. The stratigraphic sequences of the study area are compared with the stratigraphic sequence of central Nepal given by Stöcklin (1980). A geological map was prepared at the scale of 1:25,000. The geology, structures, petrography, metamorphism and mineralization of the study area are described in the following sections (Figs. 1, 2 and 3).

*Corresponding author

Email: sapkotanawraj8@gmail.com (N. Sapkota)

\section{Kuncha Formation}

The Kuncha Formation is widely distributed in BeniArthunge area. Some outcrops are seen also in Malika and Phedi of Baglung District. The sharp contact between Kuncha Formation with large outcrop of the Fagfog Quartzite is present in Kaliodar-Malika, Baglung. It is composed of greenish grey, medium-bedded, moderately weathered phyllite with abundant quartz veins. Bluish grey to dark grey micaceous phyllite is also present. Dominant wavy outcrop of thin-bedded highly foliated grey phyllite is observed at Khabara, just before Beni Bazar at the road side. The dominant lithology of Kuncha Formation is phyllite but some parts of the study area comprise; medium-bedded, highly weathered, white to yellow, finegrained quartzite, green to light green fine to coarse-grained metabasic rocks. Laminated metasandstone interbedded with phyllite also occurs in the Kuncha Formation.

\section{Fagfog Quartzite}

More than $600 \mathrm{~m}$ thick quartzite outcrop is present in the Kusma-Parbat area which extends up to Pang (NW of Kusma); the Fagfog Quartzite is medium bedded, greenish grey to pale white colored and coarse-grained. Quartzite beds are fresh to completely weathered in this section. The thickness of quartzite rapidly decreases towards Baglung from Kusma. The red color residual soil is seen on the weathered outcrop of quartzite. Cross-lamina is present as a sedimentary structure in the rock of this section. Cross-bedding showing normal sequence is found in a thick bedded yellowish white quartzite. The quartzite beds near Lower Modi Khola Hydropower Project were medium-bedded, greenish-grey and highly fractured. Highly fractured and jointed outcrops were present in the area. At the right bank of Kaligandaki River near Nayapul and at Tawai Baglung, white to yellow, medium-bedded quartzite bed is observed. Numerous boudinage structures are seen on the quartzite bed. Overturned cross bedding is present within the quartzite bed. Thin to medium-bedded, white horizontal beds 


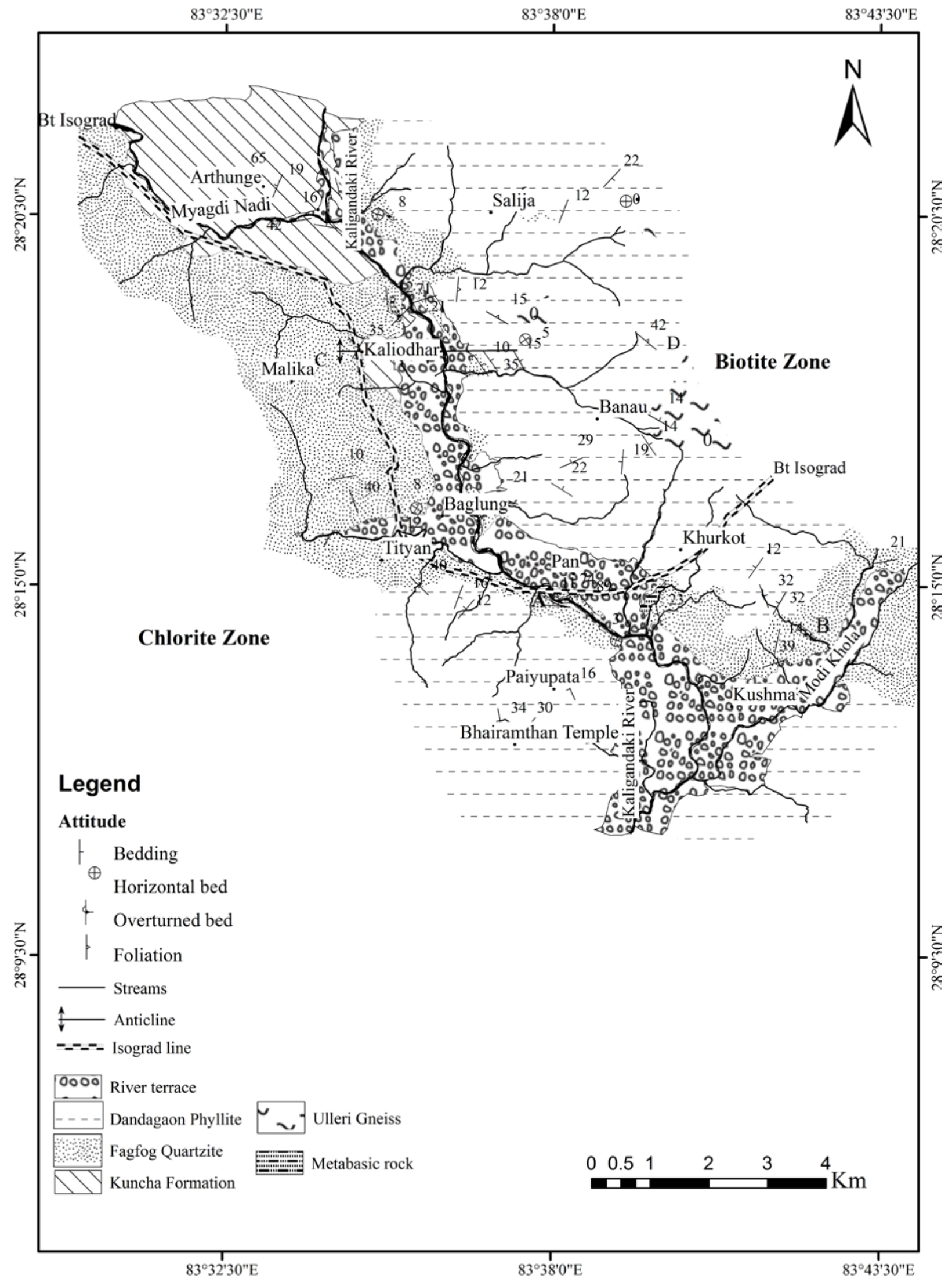

Fig. 1: Geological map of the Lesser Himalaya in Kusma-Baglung area, western Nepal. 
of quartzite were intruded by horizontal layer of metabasic rocks parallel to bedding plane representing sill structure. The quartzite bed, at the side of Kaligandaki River is covered by huge nearly vertical terrace. Quartzite beds were concordantly and discordantly intruded by metabasic rocks. Perfectly preserved cross bedding is present in the quartzite.

\section{Dandagaon Phyllite}

Most of the area under study comprises the Dandagaon Phyllite. It is composed of pelitic and psammatic schist, with fine-grained, greenish grey metasandstone. Some parts contain meta-conglomerate and bluish grey phyllite. Banau, Lasti, Dhairin and Salija area situated in NW direction from Kusma of Parbat Districts contains highly undulated psammatic schist dominantly. Frequent quartz veins with small rock crystals were present in schist and metasandstone of the study area. Meta-conglomerate with alternating bands of bluish grey phyllite and metasandstone is observed at Kharibot-Khurkot area of Parbat District, situated in north west direction from district headquarter. Alternating bands of greenish grey schist with medium bedded, light grey, weathered metasandstone is also present within this formation. Small amount of finegrained foliated, slaby quartzite bed underlies the blueish grey, thin bedded, schist near the Tare village towards Lasti from Tare. In Baglung, the Dandagaon Phyllite is present in the
Balewa-Paiyupata, SW part of the Kusma area. It comprises beds of phyllite, metasandstone, small bands of quartzite. Some bands of metabasic rocks were also present in the beds of phyllite. The beds of metasandstone comprises abundant quartz vein which contains quartz crystal. The Ulleri Gneiss is present in Banau, Dharin and Gairakharka-Salija area of Parbat District in the Dandagaon Phyllite. Le Fort (1975) studied the augen gneisses of the Nepal Himalaya and described about the genesis of Ulleri Augen Gneiss. The Ulleri Augen Gneiss comprises large amount of feldspar and alternating bands of ribbon shaped biotite. The dominance occurrence of feldspar suggests the igneous origin of the gneiss. Also some parts contain quartz as a dominant mineral with in the biotite.

\section{River Terraces}

More than $400 \mathrm{~m}$ thick deposits of river terrace is present in the study area. It was deposited by the Kaligandaki River and the Modi Khola and standing out as one of the spectacular terrace deposits in the Nepal Himalaya. The time of formation of terrace is Quaternary. It comprises fine matrix to huge boulders of the Lesser, Higher and Tethys Himalayan rocks. The clast of marble, gneiss, granite, schist, phyllite, quartzites were present in the area. Highly cemented clast with calcite matrix was present in most of the part of the old terrace. The
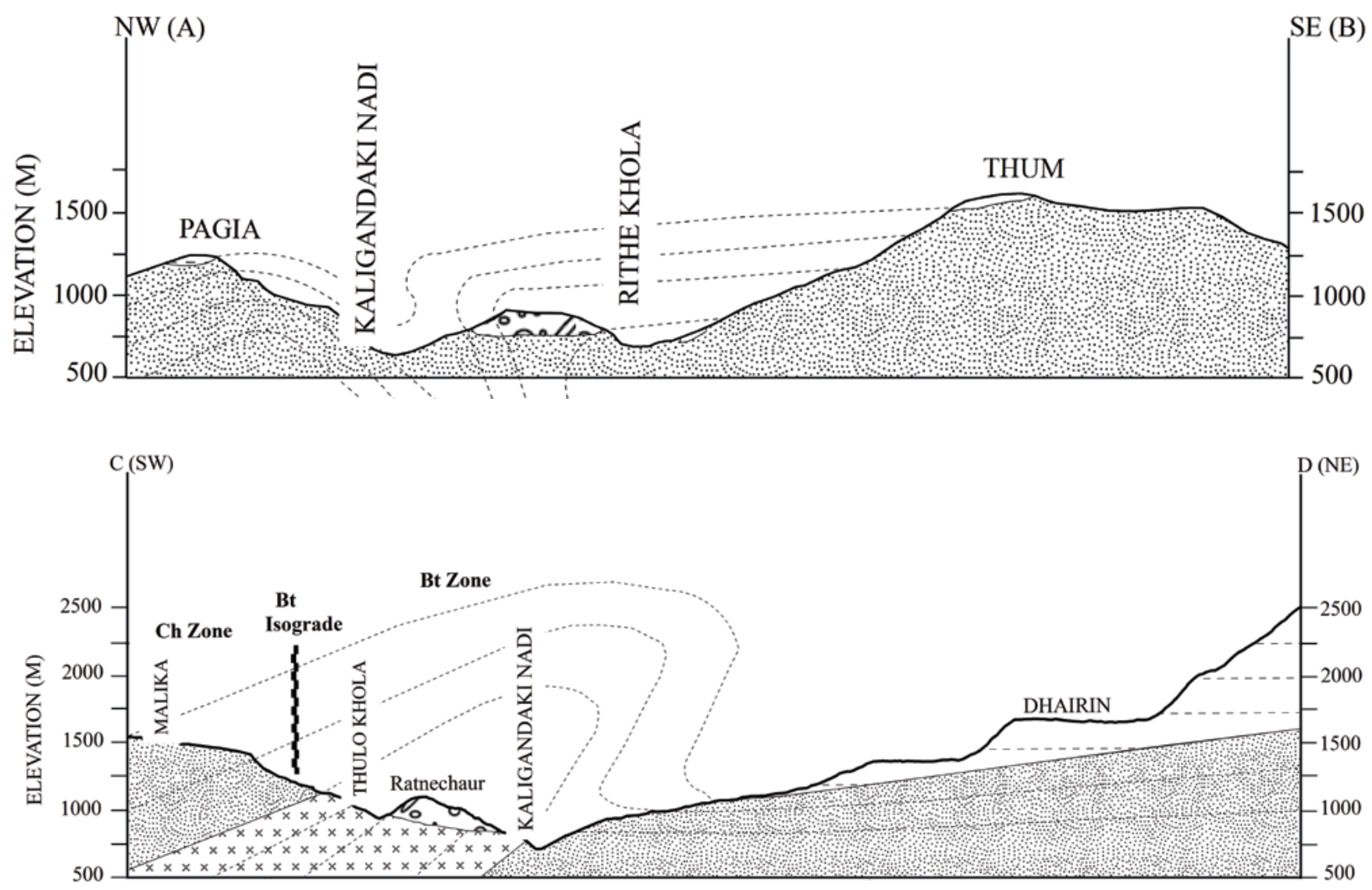

Fig. 2: Geological cross sections between point A-B and C-D. 
area contains two different sequences of terrace deposits. The first sequence of terrace is deposited by the Kaligandaki River. It shows cyclic deposition of the sediments with alternating layers of large boulders to fine cobble and pebble. Most part of the upper terrace is weathered and eroded. Most of the plain land in the study area is occupied by the terrace and being used for agricultural purpose. The top part of the terrace is used for settlements. The second sequence of terrace was made by Modi Khola which comprises three terraces similar to the Kaligandaki River. But the lithology is different in this sequence. The middle terrace developed by the Modi Khola is distributed in Chuwa, Kharea, Kusma, Gyadi area at the side of the Modi Khola. These areas comprise many of the Karstic features such as underground caves, tunnels and cavities.

\section{GEOLOGICAL STRUCTURES}

Both primary and secondary structures were present in the study area. The structures developed in rock during the time of sedimentation or shortly after the formation of rock are described as primary structures. Bedding and lamination, cross bedding, ripple marks are the primary structures present in study area. Similarly, minor folds, fault, foliation, boudinage are the secondary structures present in the field which are formed after the formation of rock at the time of deformation. The attitudes of beds taken during field visit were plotted with 'Dips' software which shows the non-cylindrical nature of fold (Fig. 4). The non-cylindrical nature of fold suggests the polyphase deformation (Davis 1942).

\section{PETROGRAPHY AND METAMORPHISM}

The study area comprises the three lithostratigraphic units. The thin section prepared from the sample collected from the Kuncha Formation contains muscovite, biotite and sericite giving the strong foliation to the phyllite (Fig. 5a). Quartz is the main constituent mineral in the sample collected from the Fagfog Quartzite. The larger grains of quartz are up to $0.04 \mathrm{~mm}$ and shows wavy margin (Fig. 5b). Thin section of metabasic rock (Fig. 5c) shows large grains of plagioclase, hornblende and chlorite. The thin section of psammatic phyllite from the Dandagaon Phyllite shows alternating band of biotite and quartz grain. The grains of quartz are elongated, and show triple junctions in some parts (Fig. 5d). Metamorphosed igneous rock, i.e, Ulleri Gneiss is present in the Dandagaon Phyllite shows large grains of plagioclase feldspar with quartz, alkali feldspar and biotite (Fig. 5e). The metaconglomerate present with in the Dandagaon Phyllite shows large grains of quartz with mafic minerals at rim (Fig. 5f). Chlorite and biotite grade of metamorphism were identified in the study area. Out of many sample of rocks collected from various parts of study area, few samples were examined under microscope by preparing thin sections to study the grade of metamorphism. Mostly southern part of the study area comprises chlorite grade and in northern part the biotite grade is in existence.

\section{MINERAL RESOURCES}

Study area comprises autochthonous sequence of the Lesser Himalayan metasedimentary rocks. The rock strata are comparable with the rocks of Lower Nawakot Group. The study area comprises roofing stones, dimension stones, sand and aggregates as industrial minerals. Crystals of garnet, kyanite, tourmaline are present in the boulders of granite and gneiss. Similarly rock crystals were collected from quartz vein present in the rocks. Malachite the ore of copper is the only metallic mineral observed in the study area. Mining of placer gold has been reported by locals but not observed in the field study. Various authors had described occurrences of placer gold in the Kaligandaki River.

\section{DISCUSSIONS}

Present study was carried out to know the geology and structures of the Kusma-Baglung-Beni area. The geological map of the study area was prepared at 1: 25,000 scale. The Kuncha Formation with bluish black to greyish white miacaceous phyllite and quartzite are the oldest strata of the study area. The Fagfog Quartzite comprises of mediumbedded, fine grained, white, cross-laminated quartzite beds. Some parts comprise greenish grey thin-bedded, highly fractured laminated quartzites. Large boudins were presents in some of the outcrops. The Dandagaon Phyllite comprises medium-bedded psammatic and pelitic schist with quartz augen and some-medium bedded yellowish white quartzite beds. The Ulleri Gneiss is present in the Dandagaon Phyllite. The Ulleri Gneiss is metamorphosed igneous volcanic sedimentary intrusion (Le Fort 1975) and comprises of large amount of plagioclase and alkali-feldspars with ribbon of biotite. Dhital et al. (2002) discuss the extension of the Kusma Quartzite from Syangja to Dang-Salyan. The rock formations of present study area are comparable with the work done by Dhital et al. (2002) in the Kusma-Syanja section and Sakai (1985). Dhital et al. (2002) identified the rocks of Lower Nawakot Group of central Nepal as well as rocks of the Tansen Group in the study area (Fig. 6). They classified the light grey-green to dark green phyllite, gritty phyllite and chlorite schist alternating with grey and grey green metasandstone into the Kuncha Formation; medium to very thick bedded, pale yellow to white quartzite into the Naudada Quartzite and so on. Similarly Sakai (1985) had studied the the Lesser Himalayan rocks of Butwal-Tansen sections and divided them into various groups and subgroups. So the present study area also comprises the similar rock type as described by the above mention author that is why the correlation of present work with the above mention previous work is purposed.

\section{CONCLUSIONS}

In the present study three lithostratigraphic units were identified. The geological map and cross sections were prepared at a scale of 1:25,000. Lithostratigraphic sequence of the area shows different type of lithology compared to that of central Nepal. Non-cylindrical fold indicating polyphase deformation in the area is identified. Two metamorphic zones; i.e, chlorite 


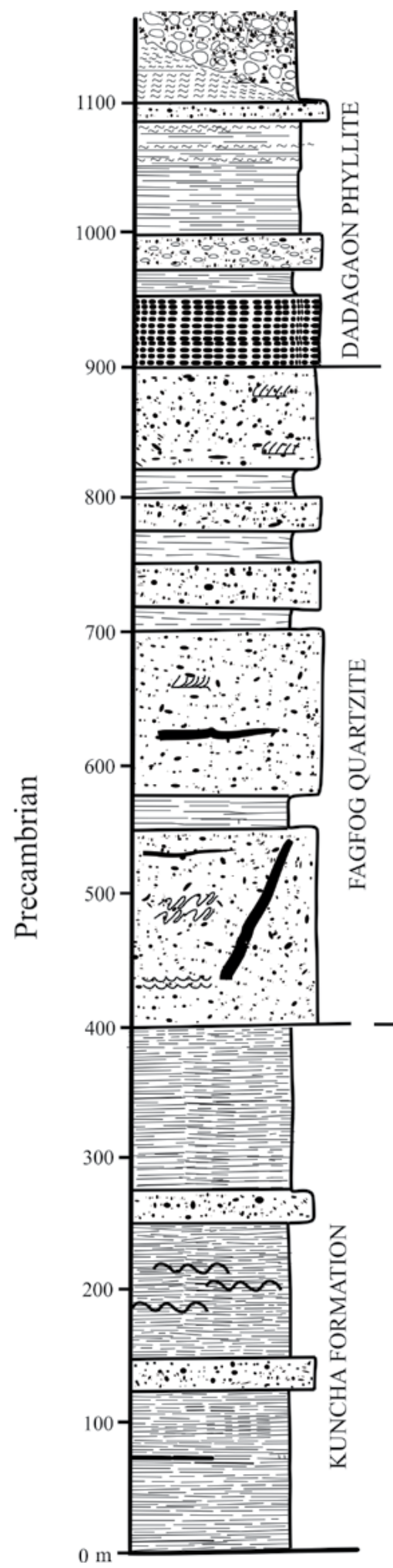

Denesly packed metaconglomerate with abundant quartz augen.

Parallel laminated, medium bedded, grey coarse-grained metasandstone with thin beds of light blue phyllite.

Very thin to thin bedded,weathered phyllite with cross laminated,thick

bedded white quartzite. Overturned cross lamina was present in some of quartzite bed.

Medium bedded white cross laminated quartzite.

Malachite mineral is found in some places,

Concordant and discordant intrusion of Metabasic rocks.

Highly weathered thin bedded greenish-grey phyllite.

Medium bedded white to greenish-grey, cross and parallel

laminated, oscillation and current ripple bearing quartzite
Fig. 3: Generalized lithostratigraphy of the study area.

zone and biotite zone were described from the petrological study. Many small scale primary and secondary structures are present in the area. The study area contains numbers of industrial minerals whereas metallic minerals shows feeble occurrence.
Medium to thin bedded, moderate to highly weathered, dark blue to greenish-grey phyllite with alternating bands of white, thin bedded, moderate to highly weathered quartzite.

Pelitic and psammatic phyllite with wavy outcrop .



Fig. 4: Lower hemispherical projection of attitudes of beds taken during field study showing scattered pole. 

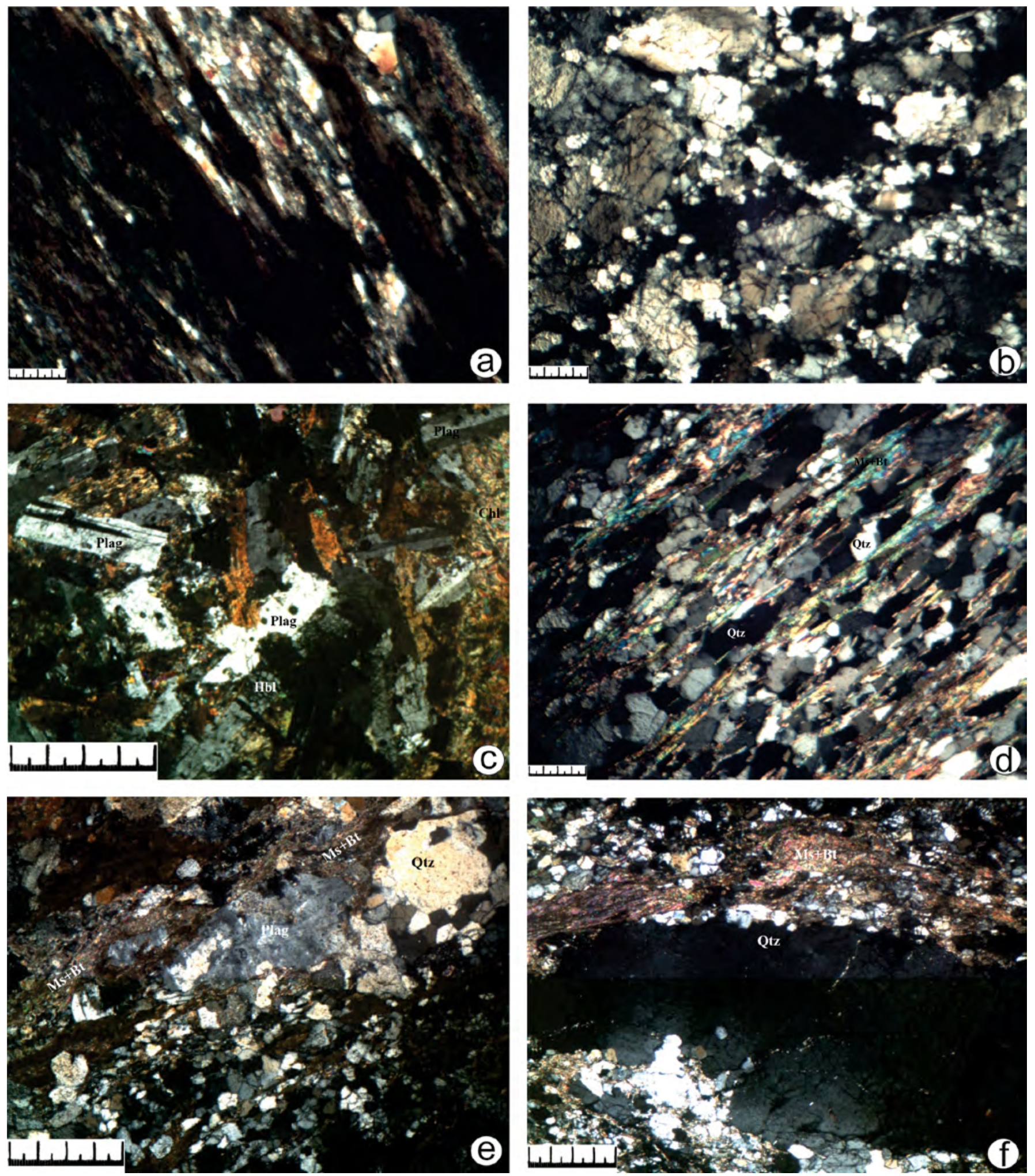

Fig. 5: (a). Photomicrograph of the Kuncha Formation at Kaliodar, Malika-Baglung, (b). Photomicrograph of the Fagfog Quartzite, at DurlungKusma road section, Parbat, (c). Photomicrograph of the metabasic rock, below Durlung, (d). Photomicrograph of the psammatic schis observed at Dhaulapahara, Salija- Parbat, (e). Photomicrograph of the Ulleri Gneiss observed at Lasti-Parbat, (f). Photomicrograph of the metaconglomerate at Halhale, Kyan-Parbat (Scale: 1 division equals $0.02 \mathrm{~mm}$ ).

\section{ACKNOWLEDGEMENTS}

This work was supported by the University Grants Commission (UGC) Nepal under faculty research grant to L.P.
Paudel. We are very much grateful to the UGC. Authors would like to thank Arjun Bhandari and Ishwor Gyawali for their assistance. We expresse sincere gratitude to the staff of Central Department of Geology (CDG) for thier help and support. 


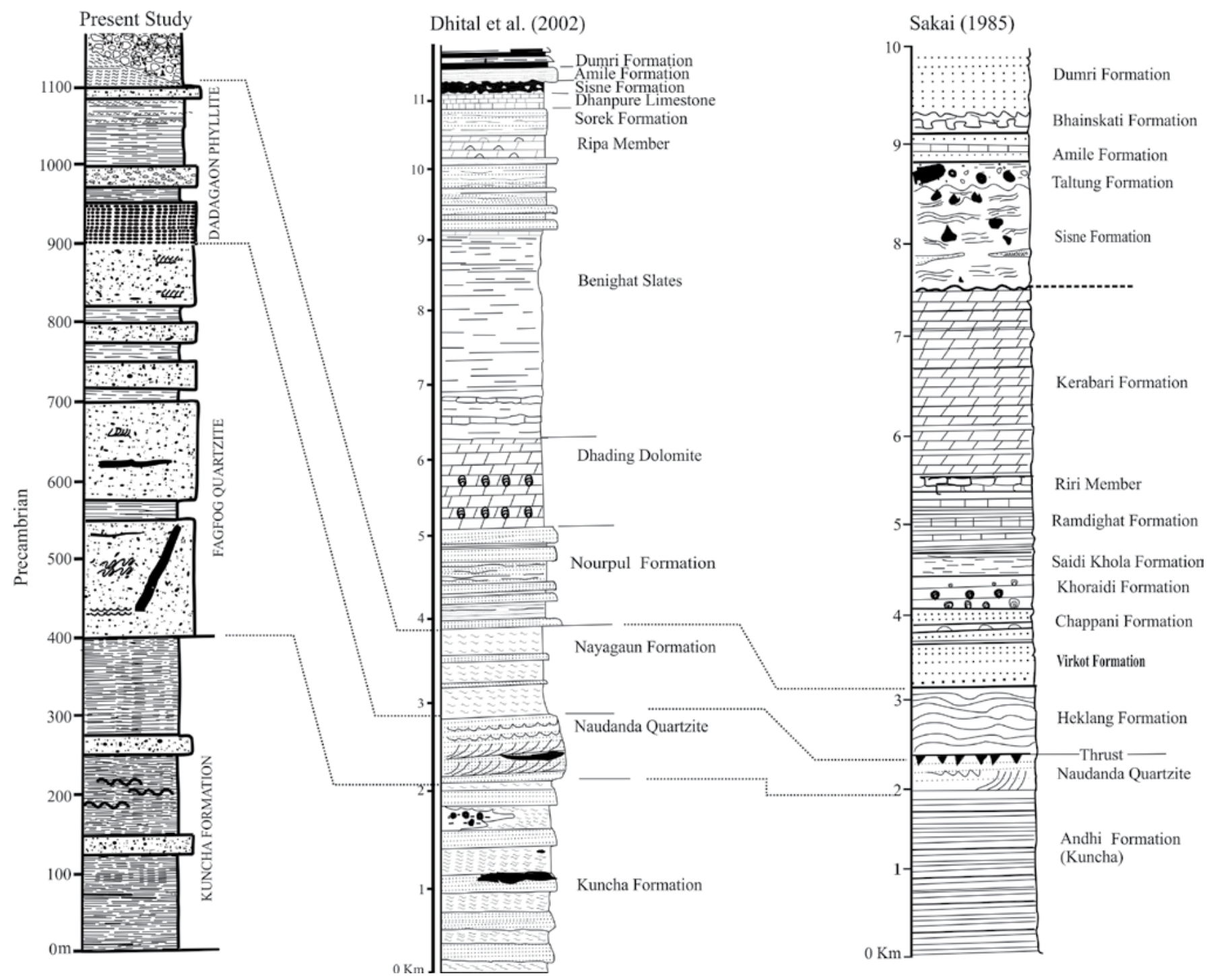

Fig. 6: Lithostratigraphic correlation of the present study with Dhital et al. (2002) and Sakai (1985).

\section{REFERENCES}

Colchen, M., Le Fort, P., and Pêcher, A, 1986. Annapurna-ManasluGanesh Himal. Centre National de la Researches Scientifique, (Sp. Publ.), $136 \mathrm{p}$.

Davis, G.H., Stephen, J.R., 1942. Structural geology of rocks and regions. Interscience, John Wiley and Sons, New York, 790 p.

Dhital, M.R., Thapa, P.B., and Ando, H., 2002. Geology of the inner Lesser Himalaya between Kusma and Syangja in western Nepal. Bull. Dept. Geol., Tribhuvan University, v. 9 (Sp. Issue), pp. 1-60.

Dhital, M.R., 2015. Geology of the Nepal Himalaya. Springer International Publishing, Switzerland, $498 \mathrm{p}$.

Duvadi, A.K., Pardhan, P.M., Shrestha, O.M., Dhaubadel, T.P. and Chand, J.B., 2004. Geological map of parts of Myagdi and Mustang Districts (eastern part), Geological map 1:50,000, Sheet no. 2663 07(62p/10). Department of Mines and Geology, His Majesty Government (HMG), pp. 1.

Fuchs, G., and Frank, W., 1970. The Geology of west Nepal between the rivers Kali Gandaki and Thulo Bheri. Jahrbuch der Gelogischen Bundesanstalt, pp. 1-103.
Godin, L., 1999. Tectonic evolution of the Tethyan Sedimentary Sequence in the Annapurna area, central Nepal Himalaya. Ph.D, Thesis, Carleton University, Ottawa, 219 p.

Hagen, T., 1969. Report on the Geological Survey of Nepal. Preliminary Reconnaissance. $169 \mathrm{p}$.

Kaneko, Y., 1995. Thermal structure in the Annapurna region central Nepal Himalaya: implication for the inverted metamorphism. Jour. Min. Pet. Eco. Geol., v. 90, pp. 143-154.

Le Fort, P., 1975. Himalayas: the collided range. present knowledge of the continental arc. American Jour. Sci., pp. 1-44.

Lamsal, S., 2016. Study on river terraces and karst landform of Kusma area, Parbat, west central Nepal. M.Sc. dissertation submitted to Central Department of Geology, Tribhuvan University, Nepal (Unpublished), $54 \mathrm{p}$.

Paudel, L.P., and Arita, K., 1998. Geology and structure and metamorphism of Lesser Himalayan metasedimentary sequence in Pokhara region, western Nepal. Jour. Nepal Geol. Soc., v. 18, pp. 97-112.

Paudel, L.P., and Arita, K., 2000. Tectonic and polymetamorphic history of Lesser Himalaya in central Nepal. Jour. Asian Earth Sci., pp. 561-584. 
Paudel, L.P., Bhandari, A., Gyawali, I., Sapkota, N., Lamsal, S., Subedi, K., and Paudyal, K.R., 2017. Characteristics of the karst landforms and related geo-hazards in the Kusma-Baglung area, western Nepal. Bull. Nepal Geol. Soc., v. 34, pp. 77-84.

Sakai, H., 1985. Geology of the Kali Gandaki Supergroup of the Lesser Himalayas in Nepal. Memoirs-Kyushu University, Faculty of Science, Series D: Geology, v. 25, pp 337-397.

Stöcklin, J., 1980. Geology of Nepal and its regional frame: Thirtythird William Smith Lecture. Jour. Geol. Soc. London, v. 137(1), pp. 1-34.
Upreti, B.N., and Merh, S.S., 1978. Geology of the area around Bhoksing-Sirkang section of the Kaligandaki valley in central west Nepal. Him. Geol., 8(3), pp. 797-812.

Yamanaka, H., Iwata, S., and Yoshida, M., 1982. Glacial landforms and river terraces in Thak-Khola region, central Nepal. Jour. Nepal Geol. Soc., v. 2 (Sp. Issue), pp. 81-9. 